\section{Cureus}

Received 12/06/2017

Review began 12/15/2017

Review ended 12/15/2017

Published 12/23/2017

\section{(c) Copyright 2017}

Khan et al. This is an open access article distributed under the terms of the Creative Commons Attribution License CC-BY 3.0., which permits unrestricted use, distribution, and reproduction in any medium, provided the original author and source are credited.

\title{
Deep Vein Thrombosis in Acute Stroke - A Systemic Review of the Literature
}

Muhammad T. Khan ${ }^{1}$, Asad Ikram ${ }^{2}$, Omar Saeed ${ }^{3}$, Taha Afridi ${ }^{4}$, Cathy A. Sila ${ }^{5}$, Matthew S. Smith ${ }^{6}$, Khadija Irshad ${ }^{7}$, Ashfaq Shuaib ${ }^{8}$

1. Neurology, Charleston Area Medical Center, Charleston, USA 2. Neurology, University of New Mexico School of Medicine, Albuquerque, USA 3. Neurology, University of Tennessee Medical Center, Chattanooga, USA 4. Hood College, Hood College, Maryland 5. Department of Neurology, University Hospitals Case Western Reserve University School of Medicine 6. Neurology, West Virginia University 7. Department of Neurology, Henry Ford Health System 8. Department of Neurology, University of Alberta

$\square$ Corresponding author: Asad Ikram, aikram@salud.unm.edu

Disclosures can be found in Additional Information at the end of the article

\section{Abstract}

We present a systemic review of available literature on the complications of deep venous thrombosis that develops in patients presenting with acute stroke. There are several pharmacological and physical treatment options available and used. We aim to summarize the management plans currently used at different centers. In conclusion, low-dose anticoagulant therapy for ischemic stroke is recommended. In the case of intracerebral hemorrhage, pneumatic sequential compression devices should be placed initially, followed by the administration of ultra-fractioned heparin on the next day, and then oral anticoagulant therapy to replace the heparin after a week in high-risk patients. Similar prophylactic treatment recommendations are used for subarachnoid hemorrhage.

Categories: Cardiology, Internal Medicine, Neurology

Keywords: dvt, acute stroke, acute stroke therapy, pneumatic compression devices, management guidelines, treatment, deep vein thrombosis

\section{Introduction And Background}

Deep vein thrombosis (DVT) is a serious complication in stroke patients and may lead to the devastating consequences of a pulmonary embolism. Both pharmacological and physical methods are used to prevent DVT. New insightful research is exploring drugs and laboratory diagnostic parameters that will aid in the early diagnosis and timely management of DVT.

\section{Epidemiology}

DVT commonly occurs in the setting of stroke and can be a fatal complication if it leads to pulmonary emboli. In immobilized post-stroke patients, the incidences of DVTs vary from 10$75 \%$, depending on the diagnostic method and time of evaluation [1-2]. Asymptomatic DVT and clinically evident DVT vary in their prevalence, the latter being 2-10\% after an acute stroke [36]. The onset of development of a DVT after acute stroke can be as early as the second day, peaking between Days 2 and 7; if left untreated, proximal DVT have a 15\% risk of death [7]. Venous thromboembolism (VTE) is also very commonly seen in patients with subarachnoid hemorrhage (SAH) or an intracerebral hemorrhage (ICH). The risk of DVT/pulmonary embolism (PE) may even be higher in patients with SAH and ICH but smallest with the transient ischemic attack (TIA) [8]. 
The most common cause of mortality from a DVT after a stroke is a PE, accounting for 13-25\% of early deaths, and their incidence usually ranges from 1-3\% in the first few months after a stroke [3-5].

The risk factors for DVT in acute stroke are advanced age, high National Institute of Health Stroke Scale (NIHSS) score, hemiparesis, immobility, female gender, atrial fibrillation, receipt of intravenous or intra-arterial tissue plasminogen activator (TPA), and admission to an academic hospital [9-11]. A recent large prospective study based on a cohort of 30,000 members of a general population in Norway documented the incidence of acute stroke and the risk of DVT and PE in patients who had a stroke. The study found that the risk of DVT and PE in their group of participants with acute ischemic stroke was independent of traditional cardiovascular risk factors, implying that stroke and related conditions (mainly immobility) are the main contributors to the VTE risk [12].

The initial test of choice for diagnosing peripheral venous thrombosis is ultrasound due to its accuracy, low cost, portability, and safety [13]. In addition, Doppler techniques provide direct information regarding flow physiology [14-16]. Either computed tomography (CT) or magnetic resonance imaging (MRI) can be used, particularly when studying central veins. Other screening tests employed are 125-I fibrinogen scanning and contrast venography. A 16-point early clinical prediction scale has been suggested to identify patients at high risk for DVT after an ischemic stroke but needs further study and validation [17].

New DVTs increased the risk of three-month mortality significantly with no influence on the combined risk of death and dependency. Increased serum C-reactive protein (CRP) levels, alongside a normal fibrinogen level, can predict the development of a new DVT. Such patients may then be reasonably protected with further DVT prophylaxis [1]. Studies that evaluated clinical factors alone could not adequately differentiate between immobile stroke patients at high or low risk, and therefore, did not formulate customized DVT prophylaxis plans. In the future, research should investigate factors, including simple blood tests, which can stratify patients according to the risk of VTE and also the risk of bleeding and identify which of these patients would have a net benefit from pharmacological prophylaxis [15]. In patients with hemorrhagic stroke, early anticoagulation is associated with a significant reduction in PE, a non-significant reduction in DVT or death, and a non-significant increase in hematoma enlargement [18].

\section{Review}

\section{Materials and methods:}

We conducted a systematic review of all published studies until June 2017 examining DVT prophylaxis in acute stroke. All studies were searched in the English language using Medline, Embase, PubMed, and the Cochrane Database. Literature search and screening strategy, studies selection, data extraction methods, and risk assessment of bias were made using predetermined criteria and supervised by one of the senior authors to maintain quality. Data were searched using the terms DVT, prophylaxis, and acute stroke. The database search identified cross-sectional studies, randomized control trials, meta-analysis, review articles, and original articles on adult human subjects.

All studies were selected which met the eligibility criteria for inclusion. The content was then reviewed by two independent investigators to determine eligibility. Any discrepancies were further resolved by using a group discussion in which a decision was made to include or exclude the study according to previously set criteria. Quality assessment was made by both reviewers evaluating whether there was a clear research question with specific results, clear description of inclusion and exclusion criteria, sound methodology, generalizability, and mentioning of 
limitations.

\section{Pharmacologic prophylaxis}

In this review, we summarize the efficacy and safety of different anticoagulant strategies in the prevention of VTE in patients with acute stroke. In patients with acute ischemic stroke, a reduction of venous thromboembolic events was noted when low-molecular-weight-heparins were used [19]. However, this slightly increased the risk of extracranial bleeding. The combined death and disability rates were reduced with the use of LMWH but could increase complications related to hemorrhage [19]. When compared with standard unfractionated heparin (UFH), the LMWHS or heparinoid appeared to decrease the occurrence of DVTs after acute ischemic strokes [20]. Comparison of UFH and LMWH revealed that low-dose LMWH had a benefit/risk ratio in patients with acute ischemic stroke by decreasing the risk of both DVT and pulmonary embolism without a clear increase in intracranial hemorrhage [21]. Based on these studies, the conclusion was that UFH and LMWH are both effective in reducing DVT and PE in patients with stroke at the cost of a slightly increased risk of hemorrhage (intracerebral and extracranial).

Unstructured Review of Unfractionated Heparin and Low-Molecular-Weight Heparin

a) Out of a series of randomized controlled trials published through January 2005 involving 23,043 patients reviewed for a comparison of early administration of either LMWH or UFH with control (placebo or no treatment) for VTE prevention in patients with acute ischemic stroke, 16 trials met the inclusion criteria [22]. Low-dose UFH ( $<15,000$ units/day) showed a decreased risk of DVT with no significant effect on risk of PE and intracranial or extracranial hemorrhage. High-dose UFH (> 15,000 units/day) reduced the risk of PE but subsequently increased the risk of both major intracranial and extracranial hemorrhage. Low-dose LMWH $(<$ $6,000 \mathrm{IU} /$ day) or a weight-adjusted dose of $<86 \mathrm{IU} / \mathrm{kg} /$ day reduced the risk of both DVT and PE and showed no increased risk of major intracranial or extracranial hemorrhage. Finally, the high-dose LMWH (> 6,000 IU/day or > $86 \mathrm{IU} / \mathrm{kg} /$ day) also decreased the risk of both DVT and PE but increased the risk of both major intracranial and extracranial bleeds [22]. The authors concluded that low-dose LMWH offered the best benefit to risk ratio for VTE prophylaxis. The numbers needed to treat (NNT) with low-dose LMWH to prevent DVT and PE were 7 and 38, respectively [22].

b) In a controlled trial that assessed UFH versus placebo effects directly and also studied VTE as a primary consequence, 305 elderly patients having an acute stroke were allocated to treatment or control groups randomly [23]. The treatment group showed a significant reduction in DVT compared with placebo as assessed by fibrinogen scanning. In patients who died, the treatment group showed an association with a significant reduction in PE at postmortem examination compared with placebo (10\% versus $46 \%)$ [23].

c) The International Stroke Trial (IST) evaluated VTE as a secondary outcome. In this trial, more than 19,000 patients were allocated to subcutaneous unfractionated heparin treatment (12,500 units twice daily or 5,000 units twice daily) versus no heparin and aspirin, $300 \mathrm{mg}$ daily, versus no aspirin $[5,21]$. The heparin treatment group showed a decline in the frequency of fatal or nonfatal PE when compared with the group not treated with heparin $(0.8 \%$ versus $0.5 \%)$, but the reduction was significant only in patients also given aspirin, $300 \mathrm{mg}$ daily. Heparin therapy was also associated with a significantly increased risk of intracranial hemorrhage compared with no heparin $(1.2 \%$ versus $0.3 \%)$ in those patients who did not receive aspirin [5].

d) The open-label prospective randomized evaluation of the "Watchman Left Atrial Appendage Closure Device in Patients with Atrial Fibrillation Versus Long-term Warfarin Therapy" (PREVAIL) trial assessed 1,762 patients with acute ischemic stroke who had leg 
weakness and could not walk unassisted were randomly assigned to subcutaneous LMWH (enoxaparin, $40 \mathrm{mg}$ daily) or subcutaneous heparin, 5,000 units every 12 hours [14]. This treatment was started within 48 hours of the onset of symptoms and lasted for 10 days (range: six to 14 days). The following 90-day outcomes were reported [14].

- Treatment with enoxaparin was associated with a significant reduction in VTE events compared with heparin treatment.

- Enoxaparin, however, showed a statistically nonsignificant reduction in PE.

- The occurrence of both major extracranial and symptomatic intracranial hemorrhage was not significantly different between both groups.

In addition to the traditional anticoagulants, the novel anticoagulants were also used in prophylaxis. For DVT prophylaxis in recent-onset acute ischemic stroke, the anti-Xa, Danaparoid (ORG 10172), when administered as 1,250 units once daily, is equally safe and efficacious as that of 5,000 IU of heparin sodium [24]. Ximelagatran, a new low-molecularweight oral prodrug of the direct thrombin inhibitor, has shown precedence over warfarin and this may make it the drug of choice for prevention of VTE.

Other medications have also been evaluated for VTE prophylaxis. In a review of one randomized controlled trial (RCT) with 17,802 participants that assessed rosuvastatin in the primary prevention of VTE, it was seen that when compared with placebo rosuvastatin reduced the incidence of deep vein thrombosis (DVT) (odds ratio (OR) 0.45; 95\% confidence interval (CI) 0.25 to 0.79$)$ [25].

\section{Mechanical prophylaxis}

Hospitalized patients with acute stroke are at high risk of DVT, and hospitals employ elastic stockings or intermittent pneumatic compression devices alone or in combination for prevention. It was observed in a randomized trial that intermittent pneumatic compression (IPC) combined with elastic stockings seemed to be more effective at reducing the rate of asymptomatic deep vein thrombosis after ICH, as compared to elastic stockings alone (4.7\% versus $15.9 \%$ ) [26]. Proximal DVTs were seen to affect those with below-knee stockings more frequently than those who employed thigh-length stockings [27]. The published data does not support the use of thigh-length graduated compression stockings (GCS) in patients admitted to hospital with acute stroke. The routine use of graduated compression stockings to reduce the risk of DVT after acute stroke is not supported by evidence gathered from randomized trials. As far as the role of IPC use for DVT risk reduction in acute stroke is concerned, the routine use of IPC to reduce the risk of DVT in acute stroke cannot be supported by sufficient evidence, and further randomized studies of IPC are needed to evaluate risks and benefits of this intervention accurately [28]. The decision to use GCS may apply to certain acute stroke patients [29]. Hence, there is insufficient evidence from randomized trials to support the routine use of physical methods for preventing DVT in acute stroke.

Data suggests that old age, female sex, bedridden patients, and high DVT assessment scores $>/=2$ are all independent risk factors for DVT in acute stroke patients that require monitoring and prophylaxis. Two-thirds of such cases can be identified on admission with the help of ultrasonography, which is also effective for DVT detection in the rehabilitation setting [27]. Following a stroke, patients may be treated with anticoagulants, mechanically or in a combination of the two. Non-ambulatory stroke patients, in particular, have an increased risk of DVT and PE. When pneumatic sequential compression devices (SCDs) are added to treatment alongside subcutaneous heparin and anti-embolic hose, reduced risk of DVT and PE are 
observed. This adjunctive treatment with SCD's should be considered for DVT prophylaxis in nonambulatory stroke patients.

The Clots in Legs Or sTockings after Stroke (CLOTS) 3 trial involved 2,876 stroke patients at 94 hospitals across the United Kingdom, and thigh-length intermittent pneumatic compression (IPC) was used. This particular study was a multicenter parallel-group randomized trial. Patients were enrolled from Day 0 to Day 3 of admission and allocated via a central randomization system (ratio: 1:1) to receive either IPC or no IPC. The CLOTS 3 study showed a $29 \%$ reduction in life-threatening DVT and a $14 \%$ reduction in overall mortality for patients receiving thigh-length IPC therapy [30].

Data does not support the use of thigh-length GCS in patients admitted to hospital with acute stroke.

However, the CLOTS 3 Trial did show a 29\% reduction in life-threatening DVT and a $14 \%$ reduction in overall mortality for patients receiving thigh-length IPC therapy [30].

\section{DVT prevention in the rehabilitation phase}

In stroke patients during the rehabilitation phase, conventional methods for prevention of DVT include adjusted-dose heparin, intermittent pneumatic compression (IPC), and functional electrical stimulation. The incidence of DVT in this phase has also been elevated and was found to occur more as distal DVT on the affected side. The contributing factors in this phase are lower limb paresis, gait disturbance, calf muscle spasticity, and use of ankle-foot orthosis (AFO). A plausible mechanism is that micro-injuries in the venous endothelium may result due to the spasticity and AFO. This damage can be prevented with the help of Cilostazol which seems to be effective following a DVT [31]. Studies evaluating data from Asian neurorehabilitation admissions revealed that asymptomatic lower limb DVT is uncommon in that region. These results may be multifactorial and include genetic or ethnic protective factors, early walking initiated rehabilitation, and timing of the admission protocol (median of 14 days post-event) when the maximal thrombotic risk decreases [32]. The low incidence of early DVT in hospitalized stroke patients of Asian ethnicity does not necessitate routine screening in this population. Further research to validate this should ideally include a comparison test for DVT, as ultrasonography may have an inherently lower sensitivity in an asymptomatic population. The incidence of venous thromboembolism is high and greatest in bedridden or wheelchairbound patients undergoing stroke rehabilitation. Further randomized trials evaluating the safety and efficacy of screening and prophylaxis of DVT in such patients are needed. Thromboprophylaxis for DVT in acute stroke patients in China is inadequate, and there is a higher usage of antiplatelet agents than anticoagulants, which has been shown to be less effective [33].

\section{DVT prophylaxis in intracranial hemorrhage}

The role of low-dose heparin treatment in patients with intracranial hemorrhage after 48 hours of onset of symptoms is not associated with an increased hematoma growth and can be used for DVT and PE prophylaxis [34]. A unique algorithm that would reduce the possibility of error in a therapeutic sense should balance various prophylactic strategies for these patients. That is why the use heparin or low-molecular-weight heparin (LMWH) in preventive doses is recommended for patients presenting with acute stroke and limited mobility if there is no contraindication for anticoagulants, along with physical therapy and mechanical methods of prophylaxis [35]. ICH patients who survived the first two days after onset and were subsequently treated with enoxaparin, $20 \mathrm{mg}$ daily, did not show an increased mortality compared to patients not on treatment [36]. 


\section{Cureus}

In particular, LMWH has been associated with a significantly lower incidence of DVT within 14 days [37]. Both aspirin and mechanical prophylaxis are suboptimal to prevent VTE. Based on studies of large numbers of stroke patients, aspirin leads to a modest reduction, if any, in pulmonary embolism. The American College of Chest Physicians (ACCP) recommends against the use of aspirin alone as a VTE prophylaxis in stroke [38]. Please review Table 1 for the detail of studies on the DVT in acute stroke, Table 2 for the different guidelines, and Table 3 on the cost comparison.

\begin{tabular}{|c|c|c|c|c|c|c|}
\hline $\begin{array}{l}\text { Study } \\
\text { author(s) }\end{array}$ & $\begin{array}{l}\text { Type of } \\
\text { study }\end{array}$ & $\begin{array}{l}\text { \# of } \\
\text { patients }\end{array}$ & $\begin{array}{l}\text { Treatments } \\
\text { studied }\end{array}$ & $\begin{array}{l}\text { Primary efficacy } \\
\text { endpoints and } \\
\text { results }\end{array}$ & $\begin{array}{l}\text { Safety } \\
\text { endpoints }\end{array}$ & Comments \\
\hline $\begin{array}{l}\text { Bembenek J, et } \\
\text { al. } 2011 \text { [1] }\end{array}$ & $\begin{array}{l}\text { Cohort } \\
\text { prospective } \\
\text { study }\end{array}$ & 299 & $\begin{array}{l}\text { LMWH as given to } \\
\text { the patients with the } \\
\text { high risk of DVT. }\end{array}$ & N/A & N/A & $\begin{array}{l}\text { Additional care to } \\
\text { patients with increased } \\
\text { serum CRP levels. }\end{array}$ \\
\hline $\begin{array}{l}\text { Soroceanu A, et } \\
\text { al. 2016 [2] }\end{array}$ & $\begin{array}{l}\text { Retrospective } \\
\text { review }\end{array}$ & 448 & $\begin{array}{l}\text { Patients undergoing } \\
\text { spinal surgery. }\end{array}$ & $\begin{array}{l}\text { Medical complications } \\
\text { including stroke, DVT, } \\
\text { and PE, were studied. }\end{array}$ & N/A & N/A \\
\hline $\begin{array}{l}\text { Kamran SI, et } \\
\text { al. } 1998 \text { [3] }\end{array}$ & Clinical trial & $\begin{array}{l}233 \text { Grp A, } \\
432 \text { Grp B, } \\
16 \text { Grp C }\end{array}$ & $\begin{array}{l}\text { Pneumatic SCDs, } \\
\text { subcutaneous } \\
\text { heparin, and anti- } \\
\text { embolic hose }\end{array}$ & N/A & N/A & $\begin{array}{l}\text { Adding SCDs to } \\
\text { treatment with } \\
\text { subcutaneous heparin } \\
\text { and anti-embolic hose } \\
\text { reduced the risk of DVT } \\
\text { and PE. }\end{array}$ \\
\hline $\begin{array}{l}\text { Kelly J, et al. } \\
2001 \text { [7] }\end{array}$ & $\begin{array}{l}\text { Review } \\
\text { Article }\end{array}$ & 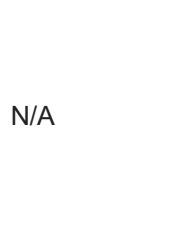 & $\begin{array}{l}\text { IVCF, } \\
\text { Anticoagulants }\end{array}$ & N/A & N/A & $\begin{array}{l}\text { Early use of short-term, } \\
\text { low-dose, UFH is not } \\
\text { associated with } \\
\text { sustained, clinically } \\
\text { meaningful benefit }\end{array}$ \\
\hline $\begin{array}{l}\text { Dennis M, et al. } \\
2011 \text { [15] } \\
\text { CLOTS (Clots } \\
\text { in Legs Or } \\
\text { sTockings after } \\
\text { Stroke) Trial } \\
\text { Collaboration }\end{array}$ & $\begin{array}{l}\text { Randomized } \\
\text { trial }\end{array}$ & $\begin{array}{l}(3,114 \text { Total) } \\
\text { 1,552 with } \\
\text { thigh-length } \\
\text { stockings } \\
\text { 1,562 with } \\
\text { below-knee } \\
\text { stockings }\end{array}$ & $\begin{array}{l}\text { Thigh length vs. } \\
\text { below knee } \\
\text { stockings }\end{array}$ & $\begin{array}{l}\text { Proximal DVT, alive } \\
\text { and free of the primary } \\
\text { outcome, or died } \\
\text { before any primary } \\
\text { outcome. }\end{array}$ & $\begin{array}{l}\text { Dead by } 30 \\
\text { days; } \\
\text { symptomatic or } \\
\text { asymptomatic } \\
\text { proximal DVT; } \\
\text { any symptomatic } \\
\text { or asymptomatic } \\
\text { DVT affecting the } \\
\text { calf, popliteal, or } \\
\text { femoral veins; or } \\
\text { pulmonary } \\
\text { emboli within } 30 \\
\text { days. }\end{array}$ & $\begin{array}{l}\text { Unfortunately, models } \\
\text { based on clinical factors } \\
\text { alone discriminate poorly } \\
\text { between immobile } \\
\text { patients with stroke at } \\
\text { high and low risk, and } \\
\text { would not facilitate } \\
\text { individual tailoring of DVT } \\
\text { prophylaxis strategies. }\end{array}$ \\
\hline $\begin{array}{l}\text { Kamerkar DR, } \\
\text { et al. } 2016 \text { [16] }\end{array}$ & $\begin{array}{l}\text { Retrospective } \\
\text { review }\end{array}$ & 549 & $\begin{array}{l}\text { Confirmed } \\
\text { diagnosis of VTE. } \\
\text { DVT confirmed by } \\
\text { Doppler } \\
\text { ultrasonography. }\end{array}$ & $\mathrm{N} / \mathrm{A}$ & N/A & $\begin{array}{l}\text { Bleeding was not the } \\
\text { limiting factor for } \\
\text { anticoagulant treatment } \\
\text { in most patients. }\end{array}$ \\
\hline
\end{tabular}




\section{Cureus}

$\begin{array}{llll}\text { Paciaroni M, et } & \text { Review } & 1,000(4 & \text { anticoagulants with } \\ \text { al. 2011 [18] } & \text { article } & \text { studies }) & \text { other treatments } \\ & & \text { like elastic stockings } \\ & & \text { and IPC. }\end{array}$

Bath PM, et al. 2000 [19]

Systemic

review of

RCTs

completed

RCTs)

\section{Kamphuisen}

PW, et al. 2005

[21]

Kamphuisen

PW, et al. 2005

[22]

Review

Review

(Multiple

studies)

article

$23,043(16$

trials)

DVT prophylaxis

N/A

Org 10172 (1250

Dumas R, et al. 1994 [24]

Clinical trial

179

2,615 (2

RCTs of

Naccarato M, et Review

al. 2010 [28]

Article

Mechanical

methods,

anticoagulants.

N/A

Symptomatic and

asymptomatic DVT,

symptomatic and

asymptomatic

pulmonary embolisms,

and death at the final

time of follow-up

(varying between

seven days and three

months)

Events during

scheduled treatment

period: 1) Deaths from

any cause; 2) DVT; 3)
N/A

Symptomatic and

asymptomatic

hematoma

enlargement

N/A

N/A

N/A

Early anticoagulation is

associated with a

significant reduction in

$\mathrm{PE}$, no substantial

reduction in death, and a

non-significant increase

in hematoma

enlargement.

LMWHs do reduce the risk of DVT and PE but only at the expense of an increased risk of major extracranial hemorrhage and probably $\mathrm{SICH}$.

Higher doses increase the risk of cerebral bleeding and should be avoided for prophylactic use. Both aspirin and mechanical prophylaxis are suboptimal to prevent VTE. GCS should be reserved for patients with a clear contraindication to antithrombotic agents.

Low-dose LMWH had the best benefit/risk ratio in patients with acute ischemic stroke by decreasing the risk of both DVT and pulmonary embolism, without a clear increase in $\mathrm{ICH}$ or $\mathrm{ECH}$.

1,250 anti-Xa units of Org 10172 once daily was both safe and as effective as 5,000 IU of heparin sodium twice daily for DVT prophylaxis in patients with acute ischemic stroke of recent onset.

\section{Events during} scheduled follow-up period: 1) Deaths from

Did not support the routine use of GCS. Insufficient evidence to 


\section{Cureus}

\begin{tabular}{|c|c|c|c|c|c|c|}
\hline & & $\begin{array}{l}\text { (2 studies of } \\
\text { IPC) }\end{array}$ & & $\begin{array}{l}\text { Fatal or non-fatal PE. } \\
\text { Adverse effects }\end{array}$ & $\begin{array}{l}\text { any cause; 2) } \\
\text { DVT; 3) Fatal or } \\
\text { non-fatal PE. }\end{array}$ & support IPC. \\
\hline $\begin{array}{l}\text { Xu B, et al. } \\
2010 \text { [29] }\end{array}$ & $\begin{array}{l}\text { Review } \\
\text { article }\end{array}$ & $\begin{array}{l}\text { Muir: 65; } \\
\text { CLOTS1: } \\
\text { 2,518; } \\
\text { Cochrane: } \\
123\end{array}$ & GCS & $\mathrm{N} / \mathrm{A}$ & $\mathrm{N} / \mathrm{A}$ & $\begin{array}{l}\text { GCS increased the risk of } \\
\text { skin problems in this } \\
\text { population. They may } \\
\text { also increase the risk of } \\
\text { critical limb ischemia and } \\
\text { are contraindicated in } \\
\text { patients with the known } \\
\text { peripheral vascular } \\
\text { disease or an ankle- } \\
\text { brachial index }<0.8 \text {. }\end{array}$ \\
\hline $\begin{array}{l}\text { Dennis M, et al. } \\
2013 \text { [30] } \\
\text { CLOTS (Clots } \\
\text { in Legs Or } \\
\text { sTockings after } \\
\text { Stroke) Trial } \\
\text { Collaboration }\end{array}$ & $\begin{array}{l}\text { Randomized } \\
\text { trial }\end{array}$ & 5,632 & $\begin{array}{l}\text { Efficacy and safety } \\
\text { of GCS }\end{array}$ & $\begin{array}{l}\text { The occurrence of } \\
\text { asymptomatic or an } \\
\text { asymptomatic DVT in } \\
\text { the popliteal or } \\
\text { femoral veins detected } \\
\text { by CDU or } \\
\text { asymptomatic DVT in } \\
\text { the popliteal or } \\
\text { femoral veins, which } \\
\text { had been confirmed } \\
\text { on imaging, within } 30 \\
\text { days of randomization. }\end{array}$ & $\begin{array}{l}\text { Secondary } \\
\text { outcomes } \\
\text { relevant to this } \\
\text { analysis include } \\
\text { death, and 'any } \\
\text { DVT' (including } \\
\text { the calf, popliteal } \\
\text { or femoral) and } \\
\text { 'symptomatic } \\
\text { DVT' within } 30 \\
\text { days. }\end{array}$ & $\begin{array}{l}\text { Models based on clinical } \\
\text { factors alone discriminate } \\
\text { poorly between immobile } \\
\text { patients with stroke at } \\
\text { high and low risk. }\end{array}$ \\
\hline $\begin{array}{l}\text { Hara Y, et al. } \\
2008[31]\end{array}$ & Original study & 272 & $\begin{array}{l}\text { Antiplatelet } \\
\text { (Cilostazol) and } \\
\text { anticoagulants }\end{array}$ & $\mathrm{N} / \mathrm{A}$ & $\mathrm{N} / \mathrm{A}$ & $\begin{array}{l}\text { Cilostazol seemed } \\
\text { effective in protecting } \\
\text { again venous endothelial } \\
\text { damage following DVT. }\end{array}$ \\
\hline $\begin{array}{l}\text { Chua K, et al. } \\
2008 \text { [32] }\end{array}$ & $\begin{array}{l}\text { Prospective } \\
\text { observational } \\
\text { single-center }\end{array}$ & 419 & $\begin{array}{l}\text { Mechanical } \\
\text { prevention. } \\
\text { Anticoagulants (in } \\
\text { selected } \\
\text { population). }\end{array}$ & $\mathrm{N} / \mathrm{A}$ & $\mathrm{N} / \mathrm{A}$ & $\begin{array}{l}\text { Asymptomatic lower limb } \\
\text { DVT is indeed } \\
\text { uncommon in Asian } \\
\text { neurorehabilitation } \\
\text { admissions. }\end{array}$ \\
\hline $\begin{array}{l}\text { Orken DN, et al. } \\
2009 \text { [34] }\end{array}$ & $\begin{array}{l}\text { Prospective } \\
\text { randomized } \\
\text { study }\end{array}$ & 75 & LMWH and GCS & $\begin{array}{l}\text { Development of } \\
\text { symptomatic or } \\
\text { asymptomatic DVT or } \\
\text { PE. }\end{array}$ & $\begin{array}{l}\text { Enlargement of } \\
\text { hemorrhage. The } \\
\text { occurrence of } \\
\text { new hemorrhage. }\end{array}$ & $\begin{array}{l}\text { Low-dose heparin } \\
\text { treatment after } 48 \text { hours } \\
\text { of stroke in ICH patients } \\
\text { is not associated with an } \\
\text { increased hematoma } \\
\text { growth and should be } \\
\text { used for DVT and PE } \\
\text { prophylaxis. }\end{array}$ \\
\hline $\begin{array}{l}\text { Zubkov AY, et } \\
\text { al. } 2009 \text { [35] }\end{array}$ & $\begin{array}{l}\text { Review } \\
\text { article }\end{array}$ & $\begin{array}{l}\text { (Multiple } \\
\text { RCTs) }\end{array}$ & $\begin{array}{l}\text { Mechanical } \\
\text { prevention, }\end{array}$ & N/A & $N / A$ & $\begin{array}{l}\text { Mechanical devices, such } \\
\text { as IPCs, significantly } \\
\text { decrease the occurrence } \\
\text { of asymptomatic DVT for } \\
\text { patients with ICH as } \\
\text { compared with elastic }\end{array}$ \\
\hline
\end{tabular}




\section{Cureus}

\begin{tabular}{|c|c|c|c|c|c|c|}
\hline & & & \multicolumn{3}{|l|}{ anticoagulants } & $\begin{array}{l}\text { stockings alone, although } \\
\text { this advantage was not } \\
\text { found in a meta-analysis } \\
\text { of prospective studies }\end{array}$ \\
\hline $\begin{array}{l}\text { Tetri S, et al. } \\
2008 \text { [36] }\end{array}$ & $\begin{array}{l}\text { Retrospective } \\
\text { study }\end{array}$ & 407 & Enoxaparin (LMWH) & $\mathrm{N} / \mathrm{A}$ & $\begin{array}{l}\text { Hematoma } \\
\text { enlargement }\end{array}$ & $\begin{array}{l}\text { No increased mortality } \\
\text { among ICH patients who } \\
\text { survived the first two } \\
\text { days after the onset of } \\
\mathrm{ICH} \text { and were afterward } \\
\text { treated with enoxaparin. }\end{array}$ \\
\hline $\begin{array}{l}\text { Bravata DM, et } \\
\text { al. } 2010 \text { [39] }\end{array}$ & $\begin{array}{l}\text { Retrospective } \\
\text { cohort study }\end{array}$ & 1,487 & $\begin{array}{l}\text { Deep vein } \\
\text { thrombosis (DVT) } \\
\text { prophylaxis, and } \\
\text { early mobilization. }\end{array}$ & $\begin{array}{l}\text { Combined endpoint of } \\
\text { hospital mortality, } \\
\text { discharge to hospice, } \\
\text { or discharge to a } \\
\text { skilled nursing facility. }\end{array}$ & $\mathrm{N} / \mathrm{A}$ & $\begin{array}{l}\text { Patients with stroke who } \\
\text { received a DVT } \\
\text { prophylaxis were less } \\
\text { likely to have poor } \\
\text { outcomes. }\end{array}$ \\
\hline $\begin{array}{l}\text { Smith EE, et al. } \\
2009 \text { [40] }\end{array}$ & Registry & $\begin{array}{l}479,284 \\
\text { (Consecutive } \\
\text { stroke and } \\
\text { TIA } \\
\text { admissions.) }\end{array}$ & $\begin{array}{l}\text { Acceptable } \\
\text { treatments: } \\
\text { Pneumatic } \\
\text { compression } \\
\text { devices and } \\
\text { anticoagulants }\end{array}$ & N/A & $\mathrm{N} / \mathrm{A}$ & $\begin{array}{l}\text { GWTG-Stroke database } \\
\text { participation was } \\
\text { associated with } \\
\text { improving quality of care } \\
\text { for hemorrhagic stroke }\end{array}$ \\
\hline $\begin{array}{l}\text { Dennis M, et al. } \\
2015 \text { [41] } \\
\text { CLOTS (Clots } \\
\text { in Legs Or } \\
\text { sTockings after } \\
\text { Stroke) Trial } \\
\text { Collaboration }\end{array}$ & $\begin{array}{l}\text { Randomized } \\
\text { trial }\end{array}$ & 2,876 & $\begin{array}{l}\text { Thigh-length } \\
\text { sleeves to both legs }\end{array}$ & $\begin{array}{l}\text { The occurrence of a } \\
\text { symptomatic or } \\
\text { asymptomatic } \\
\text { proximal DVT } \\
\text { confirmed on CDU } \\
\text { within } 30 \text { days of } \\
\text { randomization. }\end{array}$ & $\begin{array}{l}\text { Survival to six } \\
\text { months; } \\
\text { disability; and } \\
\text { hospital costs } \\
\text { (based on the } \\
\text { cost of IPC and } \\
\text { length of hospital } \\
\text { stay). }\end{array}$ & $\begin{array}{l}\text { IPC appeared to reduce } \\
\text { the risk of DVT and } \\
\text { probably improved } \\
\text { survival in all immobile } \\
\text { stroke patients. IPC } \\
\text { should be considered in } \\
\text { all immobile stroke } \\
\text { patients, but that the final } \\
\text { decision should be based } \\
\text { on individual's prognosis. }\end{array}$ \\
\hline $\begin{array}{l}\text { Hadziahmetovic } \\
\text { NV, et al. } 2009 \\
{[42]}\end{array}$ & Original study & 86 & $\begin{array}{l}\text { Aspirin, Physical } \\
\text { therapy. }\end{array}$ & N/A & N/A & $\begin{array}{l}\text { For patients with acute } \\
\text { stroke and limited } \\
\text { mobility, it was } \\
\text { recommended to use } \\
\text { heparin or LMWH in } \\
\text { preventive doses if there } \\
\text { are no contraindications } \\
\text { for anticoagulants, with } \\
\text { physical therapy and } \\
\text { mechanical methods of } \\
\text { prophylaxis. }\end{array}$ \\
\hline $\begin{array}{l}\text { Zheng H, et al. } \\
2008 \text { [43] }\end{array}$ & $\begin{array}{l}\text { Multicenter } \\
\text { prospective }\end{array}$ & 656 & $\begin{array}{l}\text { Antiplatelets, } \\
\text { anticoagulants, IPC, }\end{array}$ & N/A & $\mathrm{N} / \mathrm{A}$ & $\begin{array}{l}\text { Guidelines for preventing } \\
\text { DVT in acute stroke } \\
\text { should be established, } \\
\text { and efforts should be }\end{array}$ \\
\hline
\end{tabular}




\section{Cureus}

\begin{tabular}{|c|c|c|c|c|c|c|}
\hline & cohort study & & and stockings & & & $\begin{array}{l}\text { made to improve venous } \\
\text { thromboembolism } \\
\text { prophylaxis practice }\end{array}$ \\
\hline $\begin{array}{l}\text { Tan SS, et al. } \\
2007 \text { [44] }\end{array}$ & Case reports & 44 & $N / A$ & N/A & $N / A$ & $\begin{array}{l}\text { The institution of early } \\
\text { DVT screening with } \\
\text { Doppler ultrasound for } \\
\text { stroke patients was not } \\
\text { recommended. }\end{array}$ \\
\hline $\begin{array}{l}\text { Rabadi MH, et } \\
\text { al. } 2009 \text { [45] }\end{array}$ & $\begin{array}{l}\text { Review } \\
\text { article }\end{array}$ & (35 RCTs) & $\begin{array}{l}\text { Compression } \\
\text { stockings, IPC }\end{array}$ & N/A & $\mathrm{N} / \mathrm{A}$ & $\begin{array}{l}\text { Exercise programs for } \\
\text { community-dwelling } \\
\text { stroke patient helped } \\
\text { maintain and even } \\
\text { improve their functional } \\
\text { state. }\end{array}$ \\
\hline $\begin{array}{l}\text { Hills NK, et al. } \\
2006 \text { [46] }\end{array}$ & $\begin{array}{l}\text { Cohort } \\
\text { registry }\end{array}$ & 16,301 & DVT prophylaxis & N/A & $\mathrm{N} / \mathrm{A}$ & $\begin{array}{l}\text { Three targeted quality- } \\
\text { improvement measures } \\
\text { improved among } \\
\text { hospitals participating in } \\
\text { a disease-specific } \\
\text { registry. }\end{array}$ \\
\hline $\begin{array}{l}\text { Zorowitz RD, et } \\
\text { al. } 2005 \text { [47] }\end{array}$ & $\begin{array}{l}\text { Cohort } \\
\text { registry }\end{array}$ & 1161 & $\begin{array}{l}\text { Warfarin, heparin, } \\
\text { enoxaparin, } \\
\text { dalteparin, and } \\
\text { alteplase }\end{array}$ & $\mathrm{N} / \mathrm{A}$ & $\mathrm{N} / \mathrm{A}$ & $\begin{array}{l}\text { Unless patients have any } \\
\text { medical contraindications } \\
\text { to these medications, } \\
\text { they should receive these } \\
\text { evidence-based } \\
\text { treatments for secondary } \\
\text { stroke prophylaxis. }\end{array}$ \\
\hline $\begin{array}{l}\text { Roderick P, et } \\
\text { al. } 2005 \text { [48] }\end{array}$ & $\begin{array}{l}\text { Review } \\
\text { article }\end{array}$ & $\begin{array}{l}\text { (Multiple } \\
\text { RCTs) }\end{array}$ & $\begin{array}{l}\text { Mechanical } \\
\text { methods, oral } \\
\text { anticoagulation, } \\
\text { dextran, and } \\
\text { regional anesthesia } \\
\text { as } \\
\text { thromboprophylaxis. }\end{array}$ & $\begin{array}{l}\text { DVT, PE, and major } \\
\text { bleeding events }\end{array}$ & $\begin{array}{l}\text { Proximal venous } \\
\text { thrombosis } \\
(\mathrm{PVT}) \text { and fatal } \\
\text { PE }\end{array}$ & $\begin{array}{l}\text { There was little } \\
\text { information on the } \\
\text { prevention of VTE among } \\
\text { high-risk medical patients } \\
\text { (such as those with } \\
\text { stroke), so further } \\
\text { randomized trials in this } \\
\text { area would be helpful. }\end{array}$ \\
\hline $\begin{array}{l}\text { Wilson RD, et } \\
\text { al. } 2005 \text { [49] }\end{array}$ & $\begin{array}{l}\text { Prospective } \\
\text { study }\end{array}$ & N/A & $\begin{array}{l}\text { (Cost-effectiveness } \\
\text { analysis) }\end{array}$ & $\mathrm{N} / \mathrm{A}$ & $\mathrm{N} / \mathrm{A}$ & $\begin{array}{l}\text { This study estimates that } \\
\text { the cost-effectiveness } \\
\text { ratio was considerably } \\
\text { higher than that reported } \\
\text { in other rehabilitation } \\
\text { conditions. }\end{array}$ \\
\hline $\begin{array}{l}\text { Jaff MR, et al. } \\
2005 \text { [50] }\end{array}$ & $\begin{array}{l}\text { Multicenter } \\
\text { prospective } \\
\text { cohort study }\end{array}$ & 5,451 & IVCF placement & $N / A$ & $\mathrm{~N} / \mathrm{A}$ & $\begin{array}{l}\text { Improved physician } \\
\text { education regarding } \\
\text { mechanical and } \\
\text { pharmacologic } \\
\text { prophylaxis alternatives } \\
\text { might reduce the use of }\end{array}$ \\
\hline
\end{tabular}




\section{Cureus}

\section{TABLE 1: Studies on Deep Vein Thrombosis in Acute Stroke}

CDU: compression duplex ultrasound; CRP: C-reactive protein; DVT: deep venous thrombosis; ECH: extracranial hemorrhage; ECS: elastic compression stockings; GCS: graduated compression stockings; GWTG-Stroke: Get With The Guidelines-Stroke; ICH: intracranial hemorrhage; IPC: intermittent pneumatic compression; IU: international units; IVCF: inferior vena cava filters; LMWH: low molecular weight heparin; N/A: not available; PE: pulmonary embolism; RCTs: randomized controlled trials; SC: subcutaneous; SCDs: sequential compression devices; SICH: symptomatic intracranial hemorrhage; UFH: unfractionated heparin; VTE: venous thromboembolism

US

Guidelines

Grade 1A: Pts. with restricted mobility, prophylactic low-dose SC heparin or LMWH. Grade 1B: Pts. Contraindications to anticoagulants use IPC devices or elastic stockings.

Canadian

Guidelines

Ischemic stroke

1. Early mobilization and adequate hydration should be encouraged for all acute stroke patients to help prevent VTE (Evidence level C) 2. Patients at high risk of VTE should be started on VTE prophylaxis immediately (Evidence level A). a. LMWH should be considered for patients with acute ischemic stroke at high risk of VTE, or UFH for patients with renal failure (Evidence level B). b. The use of anti-embolism stockings alone for poststroke VTE prophylaxis is not recommended (Evidence level A).

Heparin/LMWH for prevention of venous thromboembolism after stroke only

British

Guidelines when situations of high-risk of DVT and PE arise, such as patients with major restriction of mobility, previous history of VTE, dehydration or comorbidities (such as malignant disease), and there is a low risk of bleeding.

GCS and IPC should not be used as the only prophylactic strategy (Grade B). Use of GCS as the only prophylactic strategy in patients with contraindications to pharmacological prophylaxis (Grade B). IPC should be applied in combination with GCS in patients with contraindications to pharmacological prophylaxis (Grade B). We recommend the routine use of prophylactic doses of either LMWH or UFH (5,000 IU t.i.d) for the prevention

Italian

Guidelines of VTE in patients with acute ischemic stroke (Grade A). LMWH should be preferred over UFH (Grade B). Treatment should be started within 48 hours of the acute event and should continue for approximately 14 days (Grade A). Treatment should not be administered to patients with evidence of hemorrhagic transformation (Grade D). The use of pharmacological
ICH

Grade 1 B: Pts. with an acute $\mathrm{ICH}$, the initial use of IPC devices is recommended. Grade 2 C: In stable patients, use low-dose $\mathrm{SC}$ heparin as soon as the second day after the onset of hemorrhage.

3. There is insufficient evidence on the safety and efficacy of anticoagulant DVT prophylaxis after $\mathrm{ICH}$ (Evidence level C). Antithrombotic and anticoagulants should be avoided for at least 48 hours after onset (Evidence level C).

Treatment to prevent the development of further pulmonary emboli using either anticoagulation or IVCF. (NICE guidelines)

GCS in patients with concomitant immobilization (Grade D). The need to combine the use of GCS with IPC is uncertain (Grade D). We also suggest considering the use of LMWH in immobilized patients. Patients defined at particularly high risk for VTE (Grade D). The benefit of UFH as an alternative to 


\section{Cureus}

prophylaxis should not be a contraindication for the concomitant administration of ASA (Grade B). ASA is not recommended for the prevention of DVT and PE in patients with acute ischemic stroke (Grade A).
LMWH is uncertain (Grade

D). We suggest not using ASA for the prevention of VTE (Grade D).

Australian

Guidelines

a) Early mobilization and adequate hydration should be encouraged with all acute stroke patients to help prevent DVT and PE. b) Antiplatelet therapy should be used for people with ischaemic stroke to prevent DVT/PE. (Level I) c) The following interventions may be used with caution for selected people with acute ischaemic stroke at high risk of DVT/PE: • LMWH or heparin in prophylactic doses; Level I and Level II. • Thigh-length antithrombotic stockings. Level II

\section{TABLE 2: Different Guidelines on the Management of DVT After an Acute Stroke.}

ASA: acetyl salicylic acid; CDU: compression duplex ultrasound; CRP: C-reactive protein; DVT: deep venous thrombosis; ECH: extracranial hemorrhage; ECS: elastic compression stockings; GCS: graduated compression stockings; GWTG-Stroke: Get With The Guidelines-Stroke; ICH: intracranial hemorrhage; IPC: intermittent pneumatic compression; IU: international units; IVCF: inferior vena cava filters; LMWH: low molecular weight heparin; NICE: The National Institute for Health and Care Excellence; PE: pulmonary embolism; SC: subcutaneous; SCDs: sequential compression devices; UFH: unfractionated heparin; VTE: venous thromboembolism

\begin{tabular}{ll}
\hline Medication & Cost \\
\hline Heparin, UFH/LMWH & $\$ 188 /$ day \\
Enoxaparin & $\$ 131.96 /$ day \\
Warfarin & $\$ 0.46 /$ day \\
Dabigatran & $\$ 4.09 /$ day \\
Fondaparinux & $\$ 59.3 /$ day
\end{tabular}

\section{TABLE 3: Cost Comparison of Different Medications Used in the Management of DVT.}

\section{Conclusions}

In conclusion, in light of the literature review discussed in this manuscript, we recommend the following:

For ischemic stroke, we recommend low-dose anticoagulant therapy, 5,000 units subcutaneously every eight hours.

For intracerebral hemorrhage, place SCDs on admission. On Day 2, if the patient is stable, initiate unfractionated heparin, 5,000 units subcutaneously every eight hours. On Days 10-14, if the patient is stable, one may switch to chronic oral anticoagulant therapy if there is a high risk (> 7\%/yr.) for cardioembolic stroke, with prior deep ICH at low risk $(<1.4 \% / y r$.) for 
recurrence. On discharge to a facility: continue until ambulatory.

In a subarachnoid hemorrhage, on admission place SCDs. On Day 2, if stable, initiate unfractionated heparin, 5,000 units subcutaneously every eight hours.

\section{Additional Information}

\section{Disclosures}

Conflicts of interest: In compliance with the ICMJE uniform disclosure form, all authors declare the following: Payment/services info: All authors have declared that no financial support was received from any organization for the submitted work. Financial relationships: All authors have declared that they have no financial relationships at present or within the previous three years with any organizations that might have an interest in the submitted work. Other relationships: All authors have declared that there are no other relationships or activities that could appear to have influenced the submitted work.

\section{References}

1. Bembenek J, Karlinski M, Kobayashi A, Czlonkowska A: Early stroke-related deep venous thrombosis: risk factors and influence on outcome. J Thromb Thrombolysis. 2011, 32:96-102. 10.1007/s11239-010-0548-3

2. Soroceanu A, Burton DC, Oren JH, et al.: Medical complications after adult spinal deformity surgery: incidence, risk factors, and clinical impact. Spine (Phila Pa 1976). 2016, 41:1718-23. 10.1097/BRS.0000000000001636

3. Kamran SI, Downey D, Ruff RL: Pneumatic sequential compression reduces the risk of deep vein thrombosis in stroke patients. Neurology. 1998, 50:1683-88. 10.1212/WNL.50.6.1683

4. Davenport RJ, Dennis MS, Wellwood I, Warlow CP: Complications after acute stroke. Stroke. 1996, $27: 415-20.10 .1161 / 01 . S T R .27 .3 .415$

5. International Stroke Trial Collaborative Group: The International Stroke Trial (IST): a randomised trial of aspirin, subcutaneous heparin, both, or neither among 19,435 patients with acute ischaemic stroke. Lancet. 1997, 349:1569-81. 10.1016/S0140-6736(97)04011-7

6. Kelly J, Rudd A, Lewis RR, et al.: Venous thromboembolism after acute ischemic stroke: a prospective study using magnetic resonance direct thrombus imaging. Stroke. 2004, 35:232025. 10.1161/01.STR.0000140741.13279.4f

7. Kelly J, Rudd A, Lewis R, Hunt BJ: Venous thromboembolism after acute stroke. Stroke. 2001, 32:262-67. 10.1161/01.STR.32.1.262

8. Stecker M, Michel K, Antaky K, et al.: Risk factors for dvt/pe in patients with stroke and intracranial hemorrhage. Open Neurol J. 2014, 8:1-6. 10.2174/1874205x01408010001

9. Douds GL, Hellkamp AS, Olson DM, et al.: Venous thromboembolism in the get with the guidelines-stroke acute ischemic stroke population: incidence and patterns of prophylaxis. J Stroke Cerebrovasc Dis. 2014, 23:123-29. 10.1016/j.jstrokecerebrovasdis.2012.10.018

10. Li Z, Liu L, Wang Y, et al.: Factors impact the adherence rate of prophylaxis for deep venous thrombosis in acute ischaemic stroke patients: an analysis of the China National Stroke Registry. Neurol Res. 2015, 37:427-33. 10.1179/1743132815Y.0000000035

11. Liu LP, Zheng HG, Wang DZ, et al.: Risk assessment of deep-vein thrombosis after acute stroke: a prospective study using clinical factors. CNS Neurosci Ther. 2014, 20:403-10. 10.1111/cns. 12227

12. Rinde LB, Småbrekke B, Mathiesen EB, et al.: Ischemic stroke and risk of venous thromboembolism in the general population: The Tromsø Study. J Am Heart Assoc. 2016, 5:pii: e004311. 10.1161/jaha.116.004311

13. American College of Radiology ACR Appropriateness Criteria. Clinical Condition: Suspected Lower-Extremity Deep Vein Thrombosis. (2013). Accessed: Dec 14, 2017 : http://acsearch.acr.org/docs/69416/Narrative/.

14. Sherman DG, Albers GW, Bladin C, et al.: The efficacy and safety of enoxaparin versus unfractionated heparin for the prevention of venous thromboembolism after acute ischaemic stroke (PREVAIL Study): an open-label randomised comparison. Lancet. 2007, 369:1347-55. 


\subsection{6/s0140-6736(07)60633-3}

15. Dennis M, Sandercock P, Reid J, et al.: Can clinical features distinguish between immobile patients with stroke at high and low risk of deep vein thrombosis? statistical modelling based on the CLOTS trials cohorts. J Neurol Neurosurg Psychiatry. 2011, 82:1067-73.

10.1136/jnnp.2010.235945

16. Kamerkar DR, John MJ, Desai SC, et al.: Arrive: A retrospective registry of Indian patients with venous thromboembolism. Indian J Crit Care Med. 2016, 20:150-58. 10.4103/09725229.178178

17. Li SY, Feng L, Xiao MJ, et al.: Derivation and validation of a clinical prediction scale for isolated distal deep venous thrombosis in patients after acute ischemic stroke. J Stroke Cerebrovasc Dis. 2017, 26:2087-92. 10.1016/j.jstrokecerebrovasdis.2017.04.027

18. Paciaroni M, Agnelli G, Venti M, et al.: Efficacy and safety of anticoagulants in the prevention of venous thromboembolism in patients with acute cerebral hemorrhage: a meta-analysis of controlled studies. J Thromb Haemost. 2011, 9:893-98. 10.1111/j.1538-7836.2011.04241.x

19. Bath PM, Iddenden R, Bath FJ: Low-molecular-weight heparins and heparinoids in acute ischemic stroke: a meta-analysis of randomized controlled trials. Stroke. 2000, 31:1770-78. 10.1161/01.STR.31.7.1770

20. Sandercock P, Leong TS: Low-molecular-weight heparins or heparinoids versus standard unfractionated heparin for acute ischaemic stroke. Cochrane Database Syst Rev. 2017, 4:CD000119. 10.1002/14651858.CD000119.pub4

21. Kamphuisen PW, Agnelli G, Sebastianelli M: Prevention of venous thromboembolism after acute ischemic stroke. J Thromb Haemost. 2005, 3:1187-94. 10.1111/j.15387836.2005.01443.x

22. Kamphuisen PW, Agnelli G: What is the optimal pharmacological prophylaxis for the prevention of deep-vein thrombosis and pulmonary embolism in patients with acute ischemic stroke?. Thromb Res. 2007, 119:265-74. 10.1016/j.thromres.2006.03.010

23. McCarthy ST, Turner J: Low-dose subcutaneous heparin in the prevention of deep-vein thrombosis and pulmonary emboli following acute stroke. Age Ageing. 1986, 15:84-88. 10.1093/ageing/15.2.84

24. Dumas R, Woitinas F, Kutnowski M, et al.: A multicentre, double-blind, randomized study to compare the safety and efficacy of once-daily ORG 10172 and twice-daily low-dose heparin in preventing deep-vein thrombosis in patients with acute ischaemic stroke. Age Ageing. 1994, 23:512-16. 10.1093/ageing/23.6.512

25. Li L, Zhang P, Tian JH, Yang K: Statins for primary prevention of venous thromboembolism . Cochrane Database Syst Rev. 2014, 12:CD008203. 10.1002/14651858.CD008203.pub3

26. Lacut K, Bressollette L, Le Gal G, et al.: Prevention of venous thrombosis in patients with acute intracerebral hemorrhage. Neurology. 2005, 65:865-69.

10.1212/01.wnl.0000176073.80532.a2

27. CLOTS (Clots in Legs Or sTockings after Stroke) Trial Collaboration: Thigh-length versus below-knee stockings for deep venous thrombosis prophylaxis after stroke: a randomized trial. Ann Intern Med. 2010, 153:553-62. 10.7326/0003-4819-153-9-201011020-00280

28. Naccarato M, Chiodo Grandi F, Dennis M, Sandercock PA: Physical methods for preventing deep vein thrombosis in stroke. Cochrane Database Syst Rev. 2010, 8:CD001922.

10.1002/14651858.CD001922.pub3

29. Xu B: DVT in acute stroke--the use of graduated compression stockings . Aust Fam Physician. 2010, 39:485-87.

30. CLOTS (Clots in Legs Or sTockings after Stroke) Trials Collaboration, Dennis M, Sandercock P, et al.: Effectiveness of intermittent pneumatic compression in reduction of risk of deep vein thrombosis in patients who have had a stroke (CLOTS 3): a multicentre randomised controlled trial. Lancet. 2013, 382:516-24. 10.1016/s0140-6736(13)61050-8

31. Hara Y: Deep venous thrombosis in stroke patients during rehabilitation phase . Keio J Med. 2008, 57:196-204. 10.2302/kjm.57.196

32. Chua K, Kong KH, Chan SP: Prevalence and risk factors of asymptomatic lower extremity deep venous thrombosis in Asian neurorehabilitation admissions in Singapore. Arch Phys Med Rehabil. 2008, 89:2316-23. 10.1016/j.apmr.2008.05.025

33. Zheng H, Liu L, Sun H, et al.: Prophylaxis of deep venous thrombosis and adherence to guideline recommendations among inpatients with acute stroke: results from a multicenter observational longitudinal study in China. Neurol Res. 2008, 30:370-76. 


\section{$10.1179 / 174313208 \times 300387$}

34. Orken DN, Kenangil G, Ozkurt H, et al.: Prevention of deep venous thrombosis and pulmonary embolism in patients with acute intracerebral hemorrhage. Neurologist. 2009, 15:329-31. 10.1097/NRL.0b013e3181a93bac

35. Zubkov AY, Wijdicks EF: Deep venous thrombosis prophylaxis in cerebral hemorrhage. Rev Neurol Dis. 2009, 6:21-25.

36. Tetri S, Hakala J, Juvela S, et al.: Safety of low-dose subcutaneous enoxaparin for the prevention of venous thromboembolism after primary intracerebral haemorrhage. Thromb Res. 2008, 123:206-12. 10.1016/j.thromres.2008.01.018

37. Yi X, Chi W, Wang C, et al.: Low-molecular-weight heparin or dual antiplatelet therapy is more effective than aspirin alone in preventing early neurological deterioration and improving the 6-month outcome in ischemic stroke patients. J Clin Neurol. 2015, 11:57-65. 10.3988/jcn.2015.11.1.57

38. Lansberg MG, O’Donnell MJ, Khatri P, et al.: Antithrombotic and thrombolytic therapy for ischemic stroke: Antithrombotic Therapy and Prevention of Thrombosis, 9th ed: American College of Chest Physicians Evidence-Based Clinical Practice Guidelines. Chest. 2012, 141:e601S-e636S. 10.1378/chest.11-2302

39. Bravata DM, Wells CK, Lo AC, et al.: Processes of care associated with acute stroke outcomes . Arch Intern Med. 2010, 170:804-10. 10.1001/archinternmed.2010.92

40. Smith EE, Liang L, Hernandez A, et al.: Influence of stroke subtype on quality of care in the Get With The Guidelines-Stroke Program. Neurology. 2009, 73:709-16.

10.1212/WNL.0b013e3181b59a6e

41. Dennis M, Graham C, Smith J, et al.: Which stroke patients gain most from intermittent pneumatic compression: further analyses of the CLOTS 3 trial. Int J Stroke. 2015, 10:103-107. 10.1111/ijs. 12598

42. Hadziahmetovic NV, Hadziahmetovic Z: Incidence of secondary vascular complications after stroke. Med Arh. 2009, 63:332-34.

43. Zheng H, Liu L, Sun H, et al.: Prophylaxis of deep venous thrombosis and adherence to guideline recommendations among inpatients with acute stroke: results from a multicenter observational longitudinal study in China. Neurol Res. 2008, 30:370-76.

10.1179/174313208x300387

44. Tan SS, Venketasubramanian N, Ong PL, Lim TC: Early deep vein thrombosis: incidence in Asian stroke patients. Ann Acad Med Singapore. 2007, 36:815-20.

45. Rabadi MH: Review of the randomized clinical stroke rehabilitation trials in 2009. Med Sci Monit. 2011, 17:RA25-43. 10.12659/MSM.881382

46. Hills NK, Johnston SC: Duration of hospital participation in a nationwide stroke registry is associated with improved quality of care. BMC Neurol. 2006, 6:20. 10.1186/1471-2377-6-20

47. Zorowitz RD, Smout RJ, Gassaway JA, Horn SD: Antiplatelet and anticoagulant medication usage during stroke rehabilitation: the Post-Stroke Rehabilitation Outcomes Project (PSROP). Top Stroke Rehabil. 2005, 12:11-19. 10.1310/ewcy-lj68-lhe0-54af

48. Roderick P, Ferris G, Wilson K, et al.: Towards evidence-based guidelines for the prevention of venous thromboembolism: systematic reviews of mechanical methods, oral anticoagulation, dextran and regional anaesthesia as thromboprophylaxis. Health Technol Assess. 2005, 9:iiiiv, ix-x, 1-781-78.

49. Wilson RD, Murray PK: Cost-effectiveness of screening for deep vein thrombosis by ultrasound at admission to stroke rehabilitation. Arch Phys Med Rehabil. 2005, 86:1941-48. 10.1016/j.apmr.2005.05.009

50. Jaff MR, Goldhaber SZ, Tapson VF: High utilization rate of vena cava filters in deep vein thrombosis. Thromb Haemost. 2005, 93:1117-19. 10.1160/TH04-10-0645 